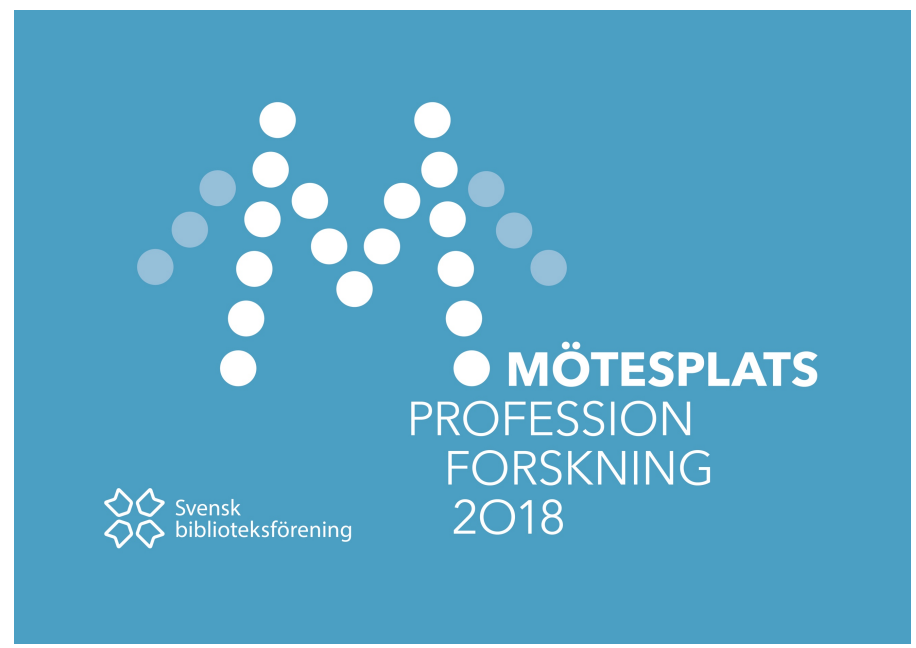

Elina Garp och Erika Lundvall

Västerås Stadsbibliotek

elina.garp@vasteras.se erika.lundvall@vasteras.se

\title{
Babybabbel - Ett språkutvecklande projekt inom Västerås Stadsbibliotek
}

\section{Inledning}

I Västerås Stadsbibliotek barnvision står det skrivet att språket är barnets viktigaste redskap genom livet. Det är via språket som barnet gör sig förstådd samt förstår sin omvärld.

Språkkompetensen lägger grunden för barnets självuppfattning, identitet och kulturtillhörighet och fungerar som verktyg i all inlärning och interaktion. Att få uttrycka sig och bli hörd är inte bara barnets rätt, utan bidrar till barnets framtida hälsa och det demokratiska samhällets utveckling. För att kunna orientera sig i och ta del av dagens komplexa samhälle behövs ett ordförråd på minst 50.000 ord. ${ }^{1}$ Det är det som behövs för att kunna klara det dagliga livet, hänga med i nyhetssändningar, förstå normal tidningstext, ta till sig instruktioner och anvisningar och för att kunna delta i demokratiska processer. Läsförståelse är en förutsättning för att kunna tillgodogöra sig skolans undervisning inom alla ämnen. Det finns en hög korrelation mellan ordförråd och läsförståelse. ${ }^{2}$ Mer än $2 \%$ okända ord i en text påverkar läsförståelsen, även förmågan att tillägna sig omvärldskunskap påverkas av hur stort ordförråd barnet har.

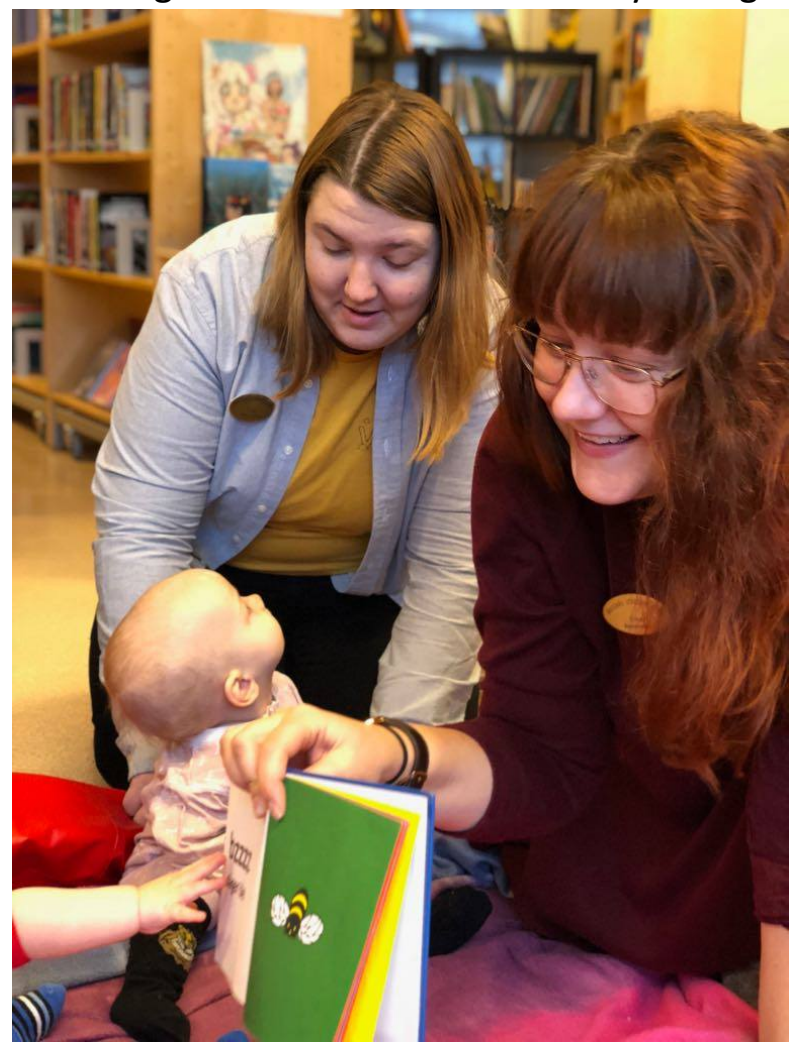

${ }^{1}$ UR-skola, Didaktorn: Jättemånga ord är jättebra. 2017.

${ }^{2}$ Liv Gjems, Förskolans arbete med tidig litteracitet, s. 155. 
I åldern 0-5 år kommer 80 \% av barns ordförråd från högläsning eller egen läsning. ${ }^{3}$ Det här innebär att det vid skolstart kan skilja oerhört mycket mellan enskilda barns ordförråd. De som har blivit lästa för, eller läst själva, har ett ordförråd på 15.000-17.000 ord medan övriga kan ha ett ordförråd på neråt $5.000-7.000$ ord. När barnen lämnar skolan i övre tonåren har barnen som startade med 15.000-17.000 ord ett ordförråd på 50.000 ord medan övriga först då har kommit upp i 17.000 ord. ${ }^{4}$ Forskningen idag anser att små barn är förprogrammerade att lära sig språk redan vid födseln, och att de har de kognitiva och perceptuella förutsättningarna för att utforska sin omvärld. ${ }^{5}$ Barnen börjar kommunicera med omvärlden direkt, via blickar, joller och skrik. Små barns språkutveckling börjar således redan vid födseln. ${ }^{6}$ Trots detta väntar många föräldrar med att läsa högt för sina barn tills de blir äldre, eller börjar aldrig med att läsa högt.

Forskning visar också att viktiga faktorer för en positiv språkutveckling är en positiv attityd till läsning i hemmet med engagerade vuxna som läser högt för barnen och att det finns tillgång till litteratur eller liknande stimulans i hemmet. ${ }^{7}$ Forskningen pekar på att förmågan att lära sig ett språk är någonting vi föds med, men förmågan att läsa är någonting som måste tränas upp och är en uppgift som kräver väldigt mycket av vår hjärna. ${ }^{8}$ Detta innebär att läsning är någonting som bör prioriteras ur ett språkutvecklande perspektiv, då så stor del av ordförrådet kommer från det skrivna språket. ${ }^{9}$ Vi på biblioteket har en unik och viktig roll som språkutvecklare och läsfrämjare, och kan vara ett stöd och en inspirationskälla för småbarnsföräldrar som är måna om sina barns språkutveckling. Vi kan tillhandahålla böcker, kunskap, en plats att vara på samt ge olika tips och råd. Eftersom barn och unga är en prioriterad målgrupp på biblioteken, är det helt i linje med vårt syfte att satsa på språkutvecklande aktiviteter för barn. Genom att arbeta med yngre barn byggs deras ordförråd från grunden vilket får en kumulativ effekt; ju fler ord barnen kan, desto lättare lär de sig nya ord. ${ }^{10}$ Detta kallas för Matteuseffekten. Barn som under sina tre till fyra första levnadsår har lärt sig många ord kommer att lära sig fler ord och kan mer om språk, medan de som inte har tillägnat sig grundläggande språkfärdigheter och lärt sig ord, ordinnebörder och fått erfarenheter av språkets struktur och grammatik kommer att ha svårare att lära sig språk. Många av dessa barn kommer alltså alltid att hamna på efterkälken jämfört med sina jämnåriga och aldrig kunna ta igen det de gått miste om under sina första levnadsår. ${ }^{11}$ Därför är det bra med tidiga insatser för de allra minsta barnen.

\section{Syfte och problemformulering}

Vi undersökte vilka aktiviteter som redan fanns för barn på Västerås stadsbibliotek och upptäckte att vi hade en lucka gällande de minsta barnen. Inga aktiviteter fanns för barn under 1 år. Trots att forskningen pekar på att det är viktigt att arbeta språkutvecklande så snart som möjligt. ${ }^{12}$ Därför ville vi fylla den här luckan och arbeta mot de minsta barnen och

\footnotetext{
${ }^{3}$ UR-skola, Didaktorn: Jättemånga ord är jättebra. 2017.

${ }^{4}$ UR-skola, Didaktorn: Jättemånga ord är jättebra. 2017.

${ }^{5}$ Louise Bjar \& Caroline Liberg (red.) Barn utvecklar sitt språk, s.57.

${ }^{6}$ Louise Bjar \& Caroline Liberg (red.) Barn utvecklar sitt språk, s.25.

${ }^{7}$ Betty Hart \& Todd R. Risley,"The Early Catastrophe: The 30 Million Word Gap by Age 3", s. 5.

${ }^{8}$ UR-skola, Didaktorn: Jättemånga ord är jättebra. 2017.

${ }^{9}$ Maryanne Wolf, Proust och bläckfisken, s. 31.

${ }^{10}$ UR-skola, Specialpedagogikens dag: Behövs språkstöd i klassrummet?, 2017.

${ }^{11}$ Liv Gjems, Förskolans arbete med tidig litteracitet, s. 55-56.

${ }^{12}$ Louise Bjar \& Caroline Liberg (red.) Barn utvecklar sitt språk, s.59-60.
} 
deras vuxna, genom ett språkutvecklande projekt. Men hur når vi de minsta barnen och deras vuxna? Hur arbetar vi språkutvecklande med så små barn?

Syftet med vårt projekt var att utveckla en språkutvecklande modell och metod för de minsta barnen och deras vuxna. Ett ytterligare syfte var att modellen och metoden sen skulle gå att genomföra i den ordinarie verksamheten, på befintlig budget och med befintliga personalresurser.

\section{Vi identifierade följande problem innan projektets början:}

- Vi hade ingen djupare kunskap om små barns språkutveckling.

- Vi upplevde inte att vi har så många personer i målgruppen vuxna med barn under 1 år på våra bibliotek.

- Vi har ingen budget att arbeta med, då inget budgeterats för de minsta barnen på grund av att inga aktiviteter tidigare funnits.

\section{Babybabbel tar form}

När vi hade identifierat problemen sökte vi lösningar på dessa. Vi anmälde oss till distanskursen; Små barns språkutveckling på Linnéuniversitetet för att vi ville få mer kunskap om hur språket utvecklas hos små barn. (Det tål att påpekas att denna kurs var på 7,5 HP på 33 \% som vi genomförde under vår fritid.) Vi tycker att Små barns språkutveckling har varit väldigt informativ och gett oss en bra grundkunskap om språkutveckling. Vi upplever båda två att det kan vara svårt att ta sig tid till egen fortbildning i en

biblioteksverksamhet där mycket annat är viktigt och kräver tid och uppmärksamhet. För oss kändes därför den här kursen som ett bra och enkelt alternativ till att själva söka information och fortbildning. Vi läste även flera böcker om projekt för de mindre barnen på bibliotek. Sakta började ett projekt ta form, som vi döpte till Babybabbel. Babybabbel består av fyra språkutvecklande träffar, med samma återkommande barn och föräldrar. Träffarna är ca 30 minuter långa och sker fyra veckor i rad. Fokus under träffarna ligger på högläsning, och olika aspekter av barns språkutveckling. I skapandet av modellen för Babybabbel använde vi oss främst av boken Bebis+bok=glädje: det underbara i att läsa högt för de allra minsta av Annette Kohkoinen, ${ }^{13}$ Baby på bibblan: inspirationsbok för bibliotek och öppen förskola av Lena Molin ${ }^{14}$ samt Barn utvecklar sitt språk av Louise Bjar och Caroline Liberg. ${ }^{15}$

Vi sökte pengar från ett regionalt projekt i Västmanland som hette "Vem äger språket?" och fick medel beviljade. Detta möjliggjorde att vi kunde få vikarier till våra ordinarie biblioteksverksamheter under de timmar vi arbetade med Babybabbel samt kunde köpa in gåvoböcker till de deltagande barnen och rekvisita. Därmed var budgetproblemet löst.

Till sist kvarstod bara problemet med att nå alla deltagare. Tre stadsdelar i Västerås valdes ut som målområden. De utvalda områdena klassas som socioekonomiskt utsatta. I dessa områden är medelinkomsten lägre än i andra områden i Västerås och barn i dessa stadsdelar har lägre läskunnighet och skolresultat än jämnåriga i andra områden. Vi affischerade på platser där vi tror vår målgrupp rör sig, på mataffärer, på apotek och i centrumbyggnader. Vi samarbetade med BVC och Öppna förskolan på de platser där träffarna skulle genomföras,

\footnotetext{
${ }^{13}$ Annette Kohkoinen, Bebis + bok= glädje : Det underbara $i$ att läsa högt för de allra minsta, 2007.

${ }^{14}$ Lena Molin, Baby på bibblan: inspirationsbok för bibliotek och öppen förskola, 2010.

${ }^{15}$ Louise Bjar \& Caroline Liberg (red.) Barn utvecklar sitt språk, 2003.
} 
för att nå personer som inte vanligtvis kom till biblioteket. Vi marknadsförde oss även på bibliotekets, Öppna förskolans och BVC:s sociala medier.

Babybabbel blev fullbokat på alla tre utvalda platser.

\section{Metod}

Vårt arbetssätt inom projektet har tagit sin inspiration från aktionsforskning.

Aktionsforskningen lägger fokus på praktiken, och genom att arbeta enligt en cyklisk forskningmodell kombineras teori och praktik. Att ifrågasätta antaganden, både våra egna och andras, är en betydelsefull aspekt av aktionsforskningen. Aktionsforskningen kan både styrka den professionella praktiken samt vidga förståelsen av bredare frågor. ${ }^{16}$

Aktionsforskning förknippas vanligtvis med praktiska, småskaliga forskningsprojekt. Karin Rönnerman definierar i boken Aktionsforskning i praktiken aktionsforskning som en idé eller ansats som tar utgångspunkt i de frågor en ställer sig själv i praktiken, verkar för att söka kunskap och djupare förståelse för dessa frågor och verkar för en forskning som leder till förändring. ${ }^{17}$ Aktionsforskning förkastar föreställningen om en process i två steg, där forskaren först bedriver sin forskning och praktikerna sedan i ett andra fristående steg tillämpar den kunskap som har genererats av forskningen. De två processerna, forskning och handling, är istället integrerade. Vi valde att använda aktionsforskning på grund av att den tar tillvara både teorin och praktikens olika styrkor och svagheter, vilket vi hoppades skulle gynna utvärderingen och utvecklingen av Babybabbelkonceptet. Rönnerman skriver att aktionsforskning kan ses ur ett "bottom up"-perspektiv, vilket innebär att det är praktikern själv som ställer frågorna och agerar för en förändring, till skillnad från ett "top down" perspektiv, där någon annan beslutar vad som ska ske i verksamheten. ${ }^{18}$ En arbetar inom aktions-forskning utifrån de olika stegen: planera - agera - observera - reflektera. Dessa steg är inte en modell som en slaviskt bör följa, utan snarare en tankegång att reflektera utifrån. ${ }^{19}$

Planera: Att formulera syfte och strävan för verksamheten, utvärdera dess förutsättningar samt planera aktioner.

Agera: Att genomföra en riktad förändring, en aktion, i verksamheten. Under Babybabbel genomfördes flera aktioner.

Observera: att vid genomförandet observera det som händer i verksamheten. Hur fungerar aktionen i praktiken? Är barnens intresserade större nu när vi ändrat bok, har vi deras uppmärksamhet?

Reflektera: Att reflektera och utvärdera de resultat som observerades, aktionens effekt på verksamheten.

Vi planerade och genomförde aktioner inför nästkommande Babybabbelträff, för att sedan observera och reflektera över dessa förändringar. Genom att kontinuerligt revidera och tänka om kring träffarnas innehåll skapade vi en möjlighet att kunna anpassa och förbättra träffarna under projektets gång. Vi tyckte att det var viktigt hur vi själva upplevde träffarna,

\footnotetext{
${ }^{16}$ Mills, Geoffrey, E. \& Butroyd, Robert. (2014). Action Research: a Guide for the Teacher Researcher. s. 3.

${ }^{17}$ Rönnerman, Karin. "Vad är aktionsforskning?". s. 21.

${ }^{18}$ Rönnerman, Karin. "Vad är aktionsforskning?". s. 22.

${ }^{19}$ Rönnerman, Karin. "Vad är aktionsforskning?". s. 22.
} 
hur de deltagande vuxna upplevde träffarna samt hur de deltagande barnen upplevde träffarna. Barnens reaktioner, när vi hade deras intresse och inte, bedömde vi själva under träffarna. Barn är väldigt kommunikativa i sina ansiktsuttryck och ögonrörelser, och vi tyckte att vi såg tydligt när de var intresserade eller inte. Efter varje träff hade vi ett kort reflekterande möte, där vi utvärderade träffen samt bestämde om något behövde ändras till nästa träff. Det kunde vara ett byte av bok, en ändring av vilken aspekt av språkutveckling vi pratade om eller bara att tala högre, exempelvis. Efter alla fyra träffar hade vi också en skriftlig utvärdering för de vuxna att fylla i. Denna cykliska process har gjort att Babybabbel ständigt utvecklas, och träffarna har därför inte sett likadana ut i början och i slutet av projektet.

\section{Babybabbelträffarna - genomförande}

Babybabbel består av fyra träffar med olika innehåll men med samma ram vid alla träffar. Såhär kan en träff se ut:

- Vi hälsar alla välkomna och tar närvaro, förklarar vilka premisser som gäller, som tex. inga mobiler och fokus på barnen.

- Inleder med en namnsång där alla sjunger med

- Högläsning av Muuu säger kon av Dick Bruna. Alla barn får se bilderna och vuxna ljudhärmar tillsammans med oss.

- Vi läser en ny bok med hjälp av rekvisita eller rörelser.

- Vi läser en ny eller en återkommande bok, som varit med på en tidigare träff.

- Boktuggarpaus i cirka 5 minuter. Barnen får undersöka böckerna med alla sinnen och föräldrarna får information om dagens tema och möjlighet att ställa frågor.

- Vi läser ytterligare en ny bok

- Avslutning med Muuu säger kon av Dick Bruna

- Avslutningssång då alla sjunger med, och träffen avslutas.

- Vi stannar kvar en stund för ytterligare frågor om någon undrar något.

Vi börjar och avslutar varje träff med en sång, för att markera ett tydligt start och slut. Sånger fångar barnens uppmärksamhet väldigt bra. Sedan läser vi en bok, som inleder och avslutar varje träff. Boken vi har valt till det är Muuu säger kon av Dick Bruna. Boken Muuu säger kon är även den första av gåvoböckerna vi delar ut. En viktig del i små barns process för språkinlärning är repetition och det är vad vi har låtit Muuu säger kon symbolisera. Eftersom Muuu säger kon är med vid varje tillfälle och deltagarna får med sig boken hem redan vid den första träffen är barnen välbekanta med Muuu säger kon när det är dags för sista träffen.

Våra kriterier för de valda böckerna är att bilderna ska passa så små barn, genom exempelvis kontrastlinjer eller passande färger. Vi märkte i vårt urvalsarbete att det fanns väldigt många böcker som hade dova färger, med mycket små detaljer och plåttriga bilder. Små barn har inte lika bra synskärpa och behöver därför bilder med tydliga kontrastfärger, och barn upp till 9 månaders ålder föredrar bilder i svart/vitt och färgerna rött, orange och gult. ${ }^{20} \mathrm{Vi}$ har också valt bort böcker med innehåll som är irrelevant för barnen, exempelvis en bok om att klä på sig med fel årstids kläder i. Vi har valt ut böcker med många svenska språkljud, ljudhärmande böcker och böcker med skön rytm att läsa högt.

\footnotetext{
${ }^{20}$ Annette Kohkoinen, Bebis + bok $=$ glädje, s.9.
} 
Ofta använder vi rekvisita eller förstärkning av ord när vi läser böckerna. När vi förstärker ord kan det vara genom att använda sig av barnriktat tal eller genom att upprepa samma ord flera gånger. Rekvisitan kan användas på flera olika sätt. Ibland har vi delat ut den i samband med läsningen så barnen får känna på den, ibland har vi bara visat rekvisitan i samband med läsningen eller använt den för att förstärka orden. Exempelvis vid ordet "köra" har vi kört runt med en liten leksaksbil.

\section{Boktuggarpaus}

Efter ungefär halva träffen är det boktuggarpaus. En boktuggarpaus går till så att vi lägger in en hög med pekböcker i mitten av filten eller sittpölen där barnen sitter. Dessa får barnen läsa och undersöka helt fritt med alla sinnen. Ofta åker de direkt in i munnen, därav namnet boktuggarpaus. Under den här tiden är barnen upptagna med att utforska, så vi kan vända vår uppmärksamhet mot de vuxna.

Det är under boktuggarpausen som vi brukar passa på att prata om olika delar av barns språkutveckling. Vi tar upp olika aspekter vid varje träff och vi pratar bland annat om vikten av läsning för ett gott ordförråd, hur munhålans utvecklas och möjliggör språkljud, om ordförrådsspurten och om språkstörning. Det finns också utrymme för frågor om någon undrar något.

\section{Träffarnas avslut}

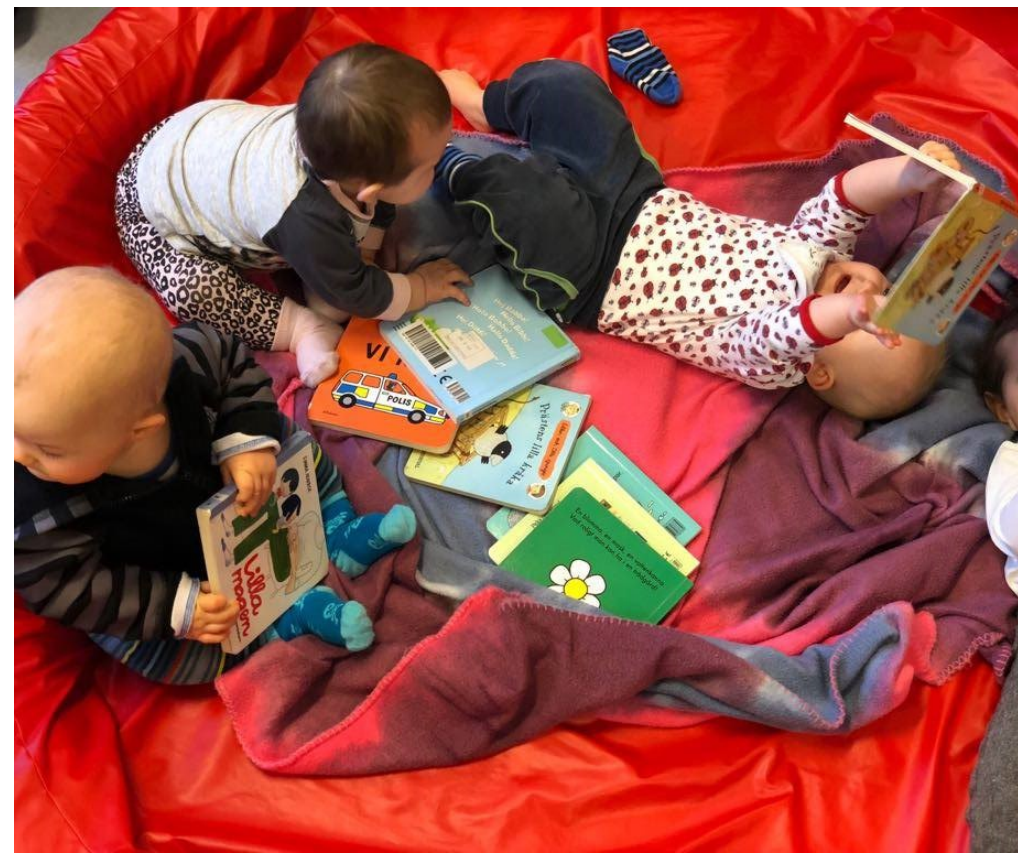

I slutet av träffarna är det ofta någon deltagare som har några frågor om språkutveckling eller vill ha boktips. Ofta tipsade de vuxna också varandra om böcker deras barn gillat eller annat intressant efter träffens slut. I slutet av varje träff delar vi också ut informationsmaterial om det vi pratat om för de vuxna att ta hem. Vi uppmuntrade de vuxna att läsa mycket hemma under träffarna, och ofta ville de vuxna också berätta om hur det gått med deras egen läsning.

\section{Hur gick det då?}

Samtliga träffar var fullbokade och det visar att viljan och intresset för språkutvecklande projekt finns hos småbarnsföräldrar. Vi upplevde inte att det blev något bortfall under projektets gång, deltagarna kom på alla fyra träffarna på sin Öppna förskola med undantag för sjukdom. Eftersom vi hade Babybabbel på tre olika platser hade vi chans att genomföra aktioner mellan träffarna, och lära av våra misstag. De olika grupperna hade lite olika dynamik, de var på olika tider på dagen och med olika personer. Gemensamt för alla grupper är att vi hade en väldigt trevlig stund tillsammans och att alla deltagare verkade överlag nöjda med träffarna. 
I utvärderingarna och i samtal med de vuxna har deltagare i alla tre grupper uppgett att Babybabbel har ökat deras intresse för läsning med sina barn och att de läser mer och oftare efter Babybabbel. Gåvoböckerna har varit en bidragande faktor till att de läser oftare, och många berättade om hur de läser Muuu säger kon hemma mellan träffarna. Flera personer har önskat fler och längre träffar, gärna ett "steg 2" när barnen blivit lite äldre. Nedan följer svar från gruppernas utvärderingar.

\section{Första gruppen}

I den första gruppens utvärderingar var det lite olika synpunkter på upplägget, vissa har tyckt att det varit bra, och andra att träffarna är för lugna och att det är för mycket fokus på läsning. Att en person som fyllde i utvärderingen dessutom satte citationstecken på "läsning" gjorde att vi tänkte till lite. Varför "läsning" och inte läsning? Vi läste ju för barnen på riktigt, och vi ville ju visa att det är otroligt viktigt att läsa för barn i den här åldern. Det handlar om riktig läsning, inte "läsning". De flesta vuxna var i alla fall överens om att Babybabbel var lagom långt och att mer sång och ramsor önskades. Vi tror att det beror på att vi under träffarna på den första platsen inte var lika tydliga när vi förklarade träffarnas upplägg och syfte. På den Öppna förskola vi var på fanns även en sång och ramsstund, som det var lite mer fart i än våra träffar. Kanske var det något liknande deltagarna hade förväntat sig? Vi pratade inte så mycket om språkutveckling i den här gruppen, eftersom vi inte ville känna oss för föreläsande, utan nämnde det lite i förbifarten när det passade. Vi förklarade inte heller alltid varför vi valde vissa böcker. Efter den här utvärderingen ändrade vi på det.

Efter den här utvärderingen inledde vi med att berätta direkt för de andra grupperna: "Detta är inte en rim \& rams- eller sångstund, utan fokus kommer vara på läsning”. Vi försökte vara tydligare och tala mer om språkutveckling, speciellt i relation till de olika böckerna. Vi lyfte fram vad som gjort att vi valt de olika böckerna, exempelvis att de hade tydliga kontrastlinjer, typiskt svenska språkljud eller att de var ljudhärmande.

Under de första träffarna i den första gruppen var vi båda lite osäkra i rollen som "babybabblare" och vi ville inte bli för föreläsande. Vi ville att det skulle råda en inkluderande atmosfär och att det skulle vara en låg tröskel till Babybabbel, alla skulle kunna vara med. Men effekten av det blev istället att vi inte kommunicerade tillräckligt väl med de vuxna angående vikten av läsning, och hur de hjälper sitt barns språkutveckling. Vilket var själva syftet med träffarna! Så efter utvärderingen fick vi oss en rejäl tankeställare.

\section{Andra gruppen}

I den andra gruppen var det flest deltagare av de tre grupperna. Det fanns åtta bokningsbara platser som var fullbokade, men utöver dessa tillkom även ytterligare personer! Nya deltagare dök upp som inte var anmälda. Det ledde till att vi hade fler deltagare under den sista träffen än på någon annan träff. Anledningen till att så många tillkom är att personalen på BVC och Öppna förskolan tyckte att det var ett bra projekt och tipsade många. Vi hade informerat om att vi ville ha en sluten grupp och att det var begränsat antal platser (vilket även stod på alla affischer och anmälningslistan). Men det kom ändå folk som bara dök upp. Många kom också för sent i den här gruppen vilket störde. Vi kände inte att vi kunde neka dem eftersom de tagit sig dit och fått information om att de var välkomna från Öppna 
förskolan och BVC. Men det var en klar skillnad för oss i koncentration mellan de barn som kom återkommande gånger och barn som dök upp för första gången på vissa träffar.

Inför den andra gruppen hade vi hunnit genomföra en del aktioner. Vi hade ändrat i namnsången, bytt lite böcker, börjat prata och sjunga högre (detta gjorde faktiskt stor skillnad, nu vågade alla klämma i mer) och fått en tydligare struktur för när vi pratar om språkutveckling och läsning. Vi började presentera alla böcker och berätta varför vi valt dem. Vi diskuterade efter tidigare deltagares önskemål i utvärderingen om vi skulle lägga till mer ramsor och sånger och bestämde oss för att radikalt nog göra helt tvärtom. Det var inte en rim \& ramsstund vi ville erbjuda, så för att klargöra det ville vi testa vad som hände om vi fokuserade nästan enbart på läsning.

Den andra gruppens utvärdering visade att vårt fokus på läsning blivit tydligare och att de vuxna uppskattade det. I den här gruppen hade vi tagit bort alla utom en ramsa.

Utvärderingen i grupp två visar att vår aktion lyckades, inga av de vuxna efterfrågade mer rim \& ramsor utan lyfte istället fram hur mycket de uppskattat läsningen. De vuxna i den andra gruppen skrev också i utvärderingen att de uppskattade att få träffa andra med barn och att få boktips, och upplevde att träffarna var bra planerade. Två vuxna lyfte även fram den information om språkutveckling vi delade med oss av som väldigt bra.

Inför den tredje gruppen genomförde vi ytterligare ett bokbyte, vi reflekterade mycket över vår egen roll som babybabblare och över hur vi kunde prata om språkutveckling utan att upplevas som föreläsande. Vi genomförde också en enkel aktion med att ordna en närvarolista och pricka av alla barn, vilket gjorde att vi lärda oss vilka barn och vuxna som hörde ihop lättare, och fick bättre koll när någon oanmäld dök upp.

\section{Tredje gruppen}

Deltagarna i den tredje och sista gruppen var väldigt nöjda med träffarna. Informationen om språkutveckling lyfts fram som toppenbra av två personer, som tyckte att det var väldigt informativa fakta på ett roligt sätt. Vi kände att det var först i den tredje gruppen vår rutin kring information om barns språkutveckling verkligen kändes naturlig och flöt på. Vi fick till många bra samtal med de vuxna, och hade bra samspel med barnen. Vi kände oss inte föreläsande på samma sätt som i de tidigare grupperna. Vi som babybabblare lyftes också fram i utvärderingarna av 3 deltagare. Deltagarna upplevde oss som engagerade, lugna och behagliga. Det var väldigt roligt eftersom vi själva reflekterat mycket över vår egen roll.

I den tredje gruppen lyfte flera fram att Babybabbel var en lugn stund med fokus på läsning som väldigt positivt, till skillnad på den första gruppen, när träffen upplevdes som för lugn. I den här gruppen kändes det som att vi fått in lite vana, vi kände oss säkrare som babybabblare och projektets koncept kändes tydligt. Deltagarna verkar dela den uppfattningen, de ville nämligen inte förändra någonting förutom att de önskade fler och längre träffar.

\section{Diskussion}

Att använda aktionsforskning som metod har möjliggjort att vi har fått åsikter och perspektiv utöver våra egna, genom enkätutvärderingarna från de deltagande vuxna. Vi har också fått en regelbundenhet i våra egna reflektioner, som ofta försvinner i projekt utan en uttalad 
metod. Istället för subjektivt tyckande kring vad som fungerar och inte, har vi haft möjlighet att pröva det empiriskt. Den cykliska modellen har passat Babybabbel bra, då det finns utrymme mellan varje träff för att hinna genomföra förändringar och utveckla Babybabbel. Eftersom vi har flera grupper med fyra träffar vardera kan vi testa nya idéer både på nästkommande träff och på kommande grupper och utvärdera resultatet av dessa förändringar. Vi har varit öppna mot deltagarna med att vi inte har haft så stor erfarenhet av tidigare arbete med de minsta barnen, och uppmuntrat dem att ge oss konstruktiv kritik i utvärderingarna. Vi har också berättat att träffarnas utformning är ett pågående arbete, och att vi är öppna för att förändra Babybabbel efter deras synpunkter.

Samtidigt som vi har tagit in och diskuterat deltagarnas utvärderingar, har vi ibland inte genomfört de förändringar de föreslagit, på grund av tidsbrist eller annat. Ibland har vi valt en annan väg mer i linje med vårt syfte med träffarna, som att förtydliga vårt fokus på läsning, istället för att införa mer sånger, rim och ramsor. I och med att vi arbetade cykliskt under projektets gång kunde vi snabbt identifiera saker som fungerade mindre bra och kunde förbättras, och testa förändringar inför nästa träff eller nästa grupp.

Vi hade även en diskussion med deltagarna om att ha fler och längre träffar. Vissa deltagare uttryckte intresse för att ha en Babybabbel steg 2, eller 1 timme långa träffar. Vi skulle gärna vilja ha ett till steg i Babybabbel, förslagsvis runt ett års ålder, då också talet börjar komma igång. Men på grund av vår begränsade budget och våra personalresurser är det inte möjligt för oss i nuläget, även om det givetvis vore väldigt roligt och givande. Längden på träffarna är också en resursfråga, men också begränsade på grund av att det ska passa barnen. Vår upplevelse är att 30 minuter är ganska lagom för de mindre barnen, i slutet av träffen kan de bli lite rastlösa och ha svårt att hålla fokus. I Baby på bibblan rekommenderades också just tiden 20-30 minuter när en jobbar med såhär små barn. ${ }^{21}$ Men självklart skulle en kunna ha längre tid efter träffen för fika och reflektion, där det finns utrymme för fler spontana frågor från de vuxna. Vi undrar också om det inte skulle kunna bli ett större bortfall av deltagare vid fler träffar. Skulle de verkligen ha möjlighet att komma varje gång? En tanke med att ha färre träffar är att det ska kännas exklusivt för de som kommer och att kvalitén på träffarna är genomgående hög. Som bibliotek så ska en ge service till flera prioriterade målgrupper och då finns det inte möjlighet att ha Babybabbel som en ordinarie verksamhet om det expanderar alldeles för mycket och blir alltför många träffar.

\section{Babybabbel som helhet}

Allt som allt har Babybabbel varit ett väldigt givande projekt. Vikten av tydlighet $i$ kommunikation är något som lyfts fram i utvärderingarna, där vi ser att sättet vi informerat de vuxna på haft en stor påverkan på deras förväntningar och deras upplevelse av Babybabbel. Under projektets gång har vi blivit bättre på att framhäva vår egen kompetens och ge praktiska råd om språkutveckling. Även att lyfta fram de olika böckerna och vad som gör just dessa böcker till bra böcker att läsa för barn, och fakta om språkutveckling generellt. Under de första träffarna var vi mer försiktiga med det eftersom vi inte ville att det skulle upplevas som "svårt" eller "en hög tröskel". Vi ville skapa en atmosfär av tillgänglighet, och att de vuxna själva kunde påverka deras barns språkutveckling, att de inte behöver vara experter för att göra skillnad. Men under de första träffarna när vi hade en mer passiv roll,

\footnotetext{
${ }^{21}$ Lena Molin, Baby på bibblan, s.39.
} 
märkte vi att deltagarna inte fick ut lika mycket av projektet. De deltog ju i Babybabbel för att de var intresserade av sina barns språkutveckling.

Det blev tydligt för oss som utförare att det fanns en skillnad i dynamiken under träffarna på de tre olika platserna vi höll Babybabbel på. Dels är ju gruppdynamiken annorlunda i olika grupper med olika människor. Dels ändrade vi en del saker mellan träffarna, som vi både fick direktrespons på samt respons på i gruppens utvärdering.

Att samarbeta med BVC och Öppna förskolan har också varit väldigt intressant, och vi har fått en bättre kontakt med personalen som jobbat där. Det har öppnat upp för fler samarbeten och bättre gemenskap våra yrkesgrupper emellan. Att arbeta uppsökande har passat Babybabbel väldigt bra och vi vill rekommendera alla att våga sig utanför de egna biblioteksdörrarna. Nästan alla deltagare på Babybabbel uppgav att de fått information on Babybabbel från BVC eller Öppna förskolan, alternativt sett våra affischer. Bara en enstaka hade fått informationen via biblioteket. Så genom att samarbeta och arbeta uppsökande nådde vi helt nya personer, som kanske inte skulle ha tagit sig till biblioteket på egen hand.

Vi har valt att inte på något sätt mäta språkutvecklingen hos barnen under projektets gång, eftersom vi inte tycker att ett mätbart resultat är syftet med projektet Babybabbel. Syftet med vårt projekt var att utveckla en språkutvecklande modell och metod för att nå de minsta barnen och deras vuxna. Ett ytterligare syfte var att modellen och metoden sen skulle gå att genomföra i den ordinarie verksamheten, på befintlig budget och med befintliga personalresurser.

Vår datainsamling bestod av våra egna reflektioner över hur barnen hade det på träffarna, vår egen upplevelse av träffarna samt de deltagande vuxnas enkäter, och var således bara kvalitativ, inte kvantitativ. Vi kan därför inte få ett mätbart resultat av barnens språkutveckling, utan mäter istället vår framgång i det intresse som Babybabbel väckte hos de deltagande vuxna, och deras positiva utvärderingssvar. Vi tror och hoppas också att Babybabbel bara var en början för deltagarna, och att de kommer att fortsätta sitt språkutvecklande arbete tillsammans med sina barn, med hjälp av tips, metoder och kunskap som de inhämtat under Babybabbelträffarma.

Vi kommer att fortsätta med Babybabbel som en del av Västerås Stadsbiblioteks ordinarie verksamhet, och nå alla Öppna förskolor \& BVC i Västerås Stad. Vi kommer att fortsätta att kontinuerligt revidera och förändra träffarnas innehåll för att Babybabbel ska fortsätta utvecklas. Språkutveckling är ett forskningsområde i ständig förändring, påverkat av ny teknik och nya forskningsrön, och Babybabbel måste följa med i den nya utvecklingen. 


\section{Litteraturförteckning}

Bjar, Louise och Liberg, Caroline. (red). 2003. Barn utvecklar sitt språk. Lund:

Studentlitteratur.

Didaktorn: Jättemånga ord är jättebra. UR-Skola, Stockholm: Sveriges utbildningsradio. 2017. https://urskola.se/Produkter/199122-Didaktorn-Jattemanga-ord-ar-jattebra [2018-08-20]

Hart, Betty \& Risley, Todd.R. (2003). "The Early Catastrophe: The 30 Million Word Gap by Age 3" American Educator, s. 4-9.

Gjems, Liv. (2018) Förskolans arbete med tidig litteracitet: på barns villkor. Lund:

Studentlitteratur.

Kohkoinen, Annette. (2007). Bebis + bok = glädje: Det underbara i att läsa högt för de allra minsta. Stockholm: En bok för alla.

Mills, Geoffrey, E. \& Butroyd, Robert. (2014). Action Research: a guide for the Teacher Researcher. Harlow: Pearson.

Molin, Lena. ( 2010). Baby på bibblan: inspirationsbok för bibliotek och öppen förskola. Lund: BTJ Förlag.

Specialpedagogikens dag: Behövs språkstöd i klassrummet? UR-Skola, Stockholm: Sveriges utbildningsradio. 2017. https://urskola.se/Produkter/200955-UR-Samtiden-

Specialpedagogikens-dag-2017-Behovs-sprakstod-i-klassrummet. [2018-08-20]

Rönnerman, Karin. (2012) "Vad är aktionsforskning". Aktionsforskning i praktiken: förskola och skola på vetenskaplig grund. Karin Rönnerman (red.). Lund: Studentlitteratur.

Vision för barnverksamheten på Västerås Stadsbibliotek, 2017. Opublicerat material. Västerås: Västerås Stadsbibliotek.

Wolf, Maryanne. (2012). Proust och bläckfisken: berättelsen och vetenskapen om den läsande hjärnan. Göteborg: Daidalos. 